\title{
Type 1 Helper Cell
}

National Cancer Institute

\section{Source}

National Cancer Institute. Type 1 Helper Cell. NCI Thesaurus. Code C12539.

Type 1 Helper Cells are a subset of helper-inducer T-lymphocytes which synthesize and secrete interleukin-2, gamma-interferon, and interleukin-12. Due to their ability to kill antigen-presenting cells and their lymphokine-mediated effector activity, these cells are associated with delayed-type hypersensitivity reactions. 